\title{
USE OF THE PRICE PRECIPITATION REACTION IN NORTHERN RHODESIA*
}

\author{
BY \\ A. J. EVANS \\ Fort Jameson, Northern Rhodesia
}

The multiplicity of tests in use for the serological diagnosis of syphilis is evidence that none of them is entirely satisfactory, even when performed in ideal conditions. The problem of finding the most efficient test for use in the tropics is one which deserves much attention. Early reports suggest that the Treponema pallidum immobilization test of Nelson and Mayer (TPI) is the most accurate test yet available, but the technical difficulties of this test make it impracticable except in the very best equipped laboratories.

In Northern Rhodesia main laboratories are few and far between, while the incidence of venereal disease is generally high and the need for accurate serological tests correspondingly great. Transport facilities to the main centres are often slow and irregular, and specimens for serological testing have to be sent long distances by road and rail in adverse climatic conditions. It is known that sera transported under such conditions will suffer deterioration. Some 4 years ago, in a small study of this problem, specimens of sera were submitted to the Kahn test, then sent on a journey of 110 miles by lorry and 200 miles by rail (the whole taking about 7 days), and then re-tested. The sera after their journey usually showed no gross bacterial contamination, but the results of the Kahn tests before and after the journey were greatly at variance. Sending freeze-dried specimens would obviate this deterioration, but it will be a very long time before this becomes a practical proposition in most parts of Africa.

As sera do not travel well to the main laboratories, it becomes obvious that ideally they must be tested locally. The question then arises as to whether the necessary antigens for the various tests will travel satisfactorily to out-stations, and whether they will retain their potency in a tropical climate for a reasonable length of time.

Price Precipitation Reaction (P.P.R.).-Various venereal disease projects undertaken by the World Health Organization have reported on the use of

*Received for publication June 11, 1954. different serological tests for syphilis in adverse climatic conditions. There have, however, been but few reports on the use of the P.P.R. test. Singh and Sharma (1951) reported its use in parallel with the V.D.R.L slide test and the Meinicke slide test. They compared the results of the three tests but did not relate the results to the clinical condition of the patients.

Price (1949) claims for this test that it is more reliable than the Kahn test, and easier to read. In the light of these claims it was decided to give the P.P.R. test a trial. It was particularly desired to test the keeping qualities of the antigen in the most adverse conditions possible.

Conditions of Trial.-A supply of antigen (Batch No. 52/B) for the P.P.R. test was obtained in London in August, 1952, and travelled by sea to Cape Town. Thence it travelled in the boot of a car to Fort Jameson, a distance of over 2,000 miles, some of it over very rough roads. On arrival the antigen stood on a shelf at room temperature for 12 months, and it was then used during September, October, and November, 1953, the three hottest months of the year. At the time of testing, it was 1 to 3 months beyond its official expiry date.

The antigen was tested in parallel with the Qualitative Kahn test and a slide modification of the Rappaport test. The Qualitative Kahn test is the standard serological test for syphilis in use throughout Central and most of East Africa. The test was carried out by the method advocated by Kahn (1950) with antigen of several different fresh batches obtained by air from the South African Institute for Medical Research, Johannesburg. The slide modification of the Rappaport test has been used as a " screen test". It is rather less sensitive than the Kahn test. Antigen for this test was made up from Kahn antigen as described by Rappaport and Eichhorn (1944). The P.P.R. test was carried out as described by Price (1948), except that, with the brighter sunshine enjoyed in Africa, it was not found necessary to read the results by a slit lamp. 
Sera for testing were obtained from

(a) the V.D. clinic at Fort Jameson and various V.D. clinics in the surrounding district.

(b) routine specimens from the ante-natal clinics,

(c) sera taken at the African Hospital as part of routine medical investigation (chiefly skin diseases, habitual abortions etc).

These sera were routinely tested by the Kahn test and Rappaport slide test ; 200 sera were selected in which the serological results with these two tests were in exact agreement with the clinical findings, and they were then submitted to the P.P.R. test.

\section{Results}

In the Table the 200 patients are classified according to their clinical condition, and the number of positive and negative results with each of the three tests are given. Some explanation is needed of the classification "Part-Treated". Many patients give a history of having had genital sores for which they have received a few injections (usually metal therapy) at a rural dispensary or mission, after which they abscond without completing their treatment. Owing to the Africans' habit of applying various forms of " native medicine", most of which result in the lesions becoming secondarily infected, healing with much scarring is the rule. The history can thus often be confirmed by the presence of

TABLE

RESULTS OF PARALLEL TESTING OF 200 SERA WITH KAHN, RAPPAPORT, AND P.P.R. TESTS

\begin{tabular}{|c|c|c|c|c|c|}
\hline \multicolumn{2}{|c|}{ Clinical Condition } & Result & Kahn & $\begin{array}{c}\text { Rappa- } \\
\text { port }\end{array}$ & P.P.R. \\
\hline \multicolumn{2}{|r|}{ Primary } & $\begin{array}{l}\text { Negative } \\
\text { Positive }\end{array}$ & $\begin{array}{r}9 \\
27\end{array}$ & $\begin{array}{l}16 \\
20\end{array}$ & $\begin{array}{l}11 \\
25\end{array}$ \\
\hline \multicolumn{2}{|r|}{ Secondary } & $\begin{array}{l}\text { Negative } \\
\text { Positive }\end{array}$ & $\overline{21}$ & $\overline{21}$ & $\overline{21}$ \\
\hline \multirow{4}{*}{ 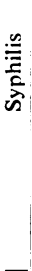 } & Tertiary & $\begin{array}{l}\text { Negative } \\
\text { Positive }\end{array}$ & $\overline{4}$ & $\overline{4}$ & $\overline{4}$ \\
\hline & Congenital & $\begin{array}{l}\text { Negative } \\
\text { Positive }\end{array}$ & $\overline{1}$ & $\overline{1}$ & $\overline{1}$ \\
\hline & $\begin{array}{c}\text { Part-treated and Un- } \\
\text { treated }\end{array}$ & $\begin{array}{l}\text { Negative } \\
\text { Positive }\end{array}$ & $\overline{29}$ & 28 & 27 \\
\hline & $\begin{array}{l}\text { Primary and Secondary } \\
\text { (at various periods } \\
\text { after treatment) }\end{array}$ & $\begin{array}{l}\text { Negative } \\
\text { Positive }\end{array}$ & 2 & $\begin{array}{l}4 \\
1\end{array}$ & 2 \\
\hline \multicolumn{2}{|c|}{ Routine Investigation } & $\begin{array}{l}\text { Negative } \\
\text { Positive }\end{array}$ & 37 & $\underline{37}$ & 37 \\
\hline \multicolumn{2}{|r|}{ Routine Ante-Natal Test } & $\begin{array}{l}\text { Negative } \\
\text { Positive }\end{array}$ & 11 & 11 & 11 \\
\hline \multicolumn{2}{|c|}{ Gonorrhoea } & $\begin{array}{l}\text { Negative } \\
\text { Positive }\end{array}$ & 52 & 52 & 52 \\
\hline \multicolumn{2}{|c|}{ Chancroid } & $\begin{array}{l}\text { Negative } \\
\text { Positive }\end{array}$ & 3 & -3 & 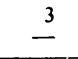 \\
\hline \multicolumn{2}{|r|}{$\begin{array}{c}\text { Lymphogranuloma } \\
\text { Inguinale }\end{array}$} & $\begin{array}{l}\text { Negative } \\
\text { Positive }\end{array}$ & 1 & 1 & 1 \\
\hline
\end{tabular}

genital scars, and such patients are classified as "Part-Treated". Patients with a history of genital sores treated with " native medicine" only are classified as "Untreated".

As the Table shows, the results obtained with the P.P.R. test were in close agreement with the other tests. In no case did the P.P.R. test give a positive result when the Kahn and Rappaport tests were negative. In two cases of early primary syphilis the Kahn test gave a weak positive and the P.P.R. a negative result. This would appear to indicate that the P.P.R. test is slightly less sensitive than the Kahn test. In only one case were completely anomalous results obtained. This patient gave a history of untreated genital sores a year previously, and his Kahn and Rappaport test were both strongly positive while his P.P.R. test was negative. All tests on this patient were repeated a fortnight later with the same results. It is believed that this anomalous result was due to a zone phenomenon with the P.P.R. test. In every other case the Kahn and P.P.R. results were in complete agreement. The rather less sensitive slide modification of the Rappaport test gave more negative results in cases of primary syphilis and in post-treatment cases. Of the total of 200 sera tested, 41 were collected from outside clinics and had travelled 50 to 150 miles over bad roads for 24 to 48 hours before reaching the refrigerator. It was noted with surprise that no anomalous results between the three tests were found among these 41 sera.

No attempt has been made to assess the occurrence of false biological reactions with the P.P.R. test. All " problem " sera were excluded from the trial. Only those sera in which the serological results with the other two tests agreed with the clinical findings were subsequently submitted to the P.P.R. test.

\section{Summary}

The Price Precipitation Reaction has been tested in a small series in parallel with the Qualitative Kahn test and a slide modification of the Rappaport test in a tropical climate. The results show that the P.P.R. test works satisfactorily, and that the antigen is sufficiently robust to retain its potency in adverse conditions.

My thanks are due to the Director of Medical Services, Northern Rhodesia, for permission to publish these findings.

\section{REFERENCES}

Kahn, R. L. (1950). “ "Serology with Lipid Antigen". Williams and Wilkins, Baltimore.

Price, I. N. O. (1948). J. clin. Path., 1, 91.

- (1949). British Journal of Venereal Diseases, 25, 67.

Rappaport, F., and Eichhorn, F. (1944). Lancet, 2, 599.

Singh, B., and Sharma, M. D. (1951). British Journal of Venereal Diseases, 27, 190 . 